\title{
MODEL PEMBELAJARAN DAS PADA MATERI BERPIDATO DENGAN MENGGUNAKAN BAHASA INGGRIS SISWA DI KELAS IXMADRASAH TSANAWIYAH NEGERI BINJAI SEMESTER GANJIL
}

\author{
Sri Rahayu Kesumawati
}

Surel:kesumawatisrirahayu@gmail.com

\begin{abstract}
This study aims to find out the DAS learning model (Listen, Observe, Convey) on speaking material using English can improve students' English learning outcomes in class IX of MTsN Binjai odd semester of the 2019/2020 school year. This research consists of two cycles. The results showed that the DAS (Listen, Observe, Convey) learning model on speaking materials using English could improve English learning outcomes and student activities in class IX of MTsN Binjai in the odd semester of the 2019/2020 school year. This can be seen from the results of the calculation in the first cycle between the test scores of the first block and the test scores of the second block, the correlation of the moment $r$ arithmetic products is 0.846 , and the t-test value is 8.983, and in the second cycle between the third block test scores and the fourth block test scores. The product correlation of moment $r$ count is 0.925 , and the t test value is 13,808, while all the calculated $r$ values are greater than the r table of 0.478 , also the t count is greater than the t table test of 2.725 , and can also be seen from the results of student attendance in the first cycle the attendance was around $90 \%$, and in the second cycle the attendance was around 95\%, and increased to $100 \%$.
\end{abstract}

Keywords: Learning Model, Watershed, Speech

\begin{abstract}
ABSTRAK
Penelitian ini bertujuan untuk Untuk mengetahui model pembelajaran DAS (Dengar, Amati, Sampaikan) pada materi Berpidato dengan menggunakan bahasa Inggris dapat meningkatkan hasil belajar bahasa Inggris siswa di kelas IX MTsN Binjai semester ganjil tahun pelajaran 2019/2020. Penelitian ini terdiri dari dua siklus. Hasil penelitian menunjukkan bahwa model pembelajaran DAS (Dengar, Amati, Sampaikan) pada materi Berpidato dengan menggunakan bahasa Inggris dapat meningkatkan hasil belajar bahasa Inggris dan aktivitas siswa di kelas IX MTsN Binjai semester ganjil tahun pelajaran 2019/2020. Hal ini dapat dilihat dari hasil hitung pada siklus pertama antara nilai ujian blok pertama dengan nilai ujian blok kedua diperoleh korelasi produk moment $\mathrm{r}$ hitung sebesar 0,846 , dan nilai uji $\mathrm{t}$ sebesar 8,983, dan pada siklus kedua antara nilai ujian blok ketiga dengan nilai ujian blok keempat diperoleh korelasi produk moment $r$ hitung sebesar 0,925 , dan nilai uji t sebesar 13,808 , sementara semua nilai $r$ hitung lebih besar dari $r$ tabel sebesar 0,478 , juga t hitung lebih besar dari uji t tabel sebesar 2,725, dan juga dapat dilihat dari hasil absensi kehadiran siswa pada siklus pertama kehadiran sekitar $90 \%$, dan pada siklus kedua kehadiran sekitar $95 \%$, dan meningkat menjadi $100 \%$.
\end{abstract}

Kata Kunci: Model Pembelajaran, DAS, Berpidato 
Sri Rahayu Kesumawati : Model Pembelajaran DAS ...

\section{PENDAHULUAN}

Pendidikan

gerbang menuju bangsa yang bermartabat. amat mustahil untuk mencapai bangsa yang bermaratabat tanpa melalui dunia pendidikan. Dunia pendidikan berarti dunia guru. Dengan kata lain gurulah yang menjadi ujung tombak untuk menciptakan pendidikan yang bermutu sehingga dapat mencapai bangsa yang bermartabat. Bila ada guru yang merasa bahwa dunia pendidikan bukanlah dunianya, berarti guru tersebut tidak layak menjadi seorang guru. Jadi guru yang sejati harus selalu berhubungan dengan pernak pernik pendidikan. Yang dimaksud dengan pernak pernik itu tentu saja sangat erat kaitannya dengan konsekwensi profesi guru sesuai dengan bidang pembelajaran yang diembannya. Mau tidak mau, suka tidak suka guru senantiasa luwes dalam menata perilaku, menata pembelajaran, menata pesrta didikdan segala hal yang berkaitan dengan profesinya. Jangan sampai ada materi yang tertinggal atau sengaja ditinggalkan karena kebetulan materi tersebut membosankan bagi peserta didik ataupun bagi guru atau karena alasan lainnya. Guru harus kreatif sehingga semua materi ajar menjadi materi yang menyenangkan. Minimal tidak membosan kan.

Berbicara merupakan salah satu aspek keterampilan berbahasa yang diharapkan dapat dikuasai siswa setelah menyelesaikan pendidikannya pada tingkat Madrasah Tsanawiyah Negeri Binjai. Keterampilan lainnya adalah mendengar kan, menyimak menulis dan membaca.Berbicara (baca berpidato) memiliki peranan penting dalam mencapai suatu tujuan. Hal ini sudah banyak dibuktikan oleh tokoh-tokoh partai maupun tokoh masyarakat baik pada zaman dahulu maupun pada masa sekarang. Bacalah sejarah, kita akan tahu bagaimana dengan keahliannya berpidato Ir soekarno dapat membangkitkan semangat rakyat. Dengan keahlian berpidato pula tokoh-tokoh partai masa kini mampu menarik simpati masyarakat hingga memperoleh dukungan yang besar bagi kursi kepemimpinannya. Kemampuan berpidato membuat seseorang mudah diterima oleh orang-orang yang ada disekelilingnya. Tak salah jika ada peribahasa " mereka yang memiliki keahlian berbicara dengan mudah dapat menguasai massa, dapat berhasil mendesakkan ide mereka sehingga dapat diterima oleh orangorang lain."

Berpidato erat kaitannya dengan menyimak (mendengarkan) bukankah hanya orang yang kurang waras saja yang suka berbicara sendiri tanpa perduli ada atau tidak orang yang mendengarkannya. Tapi ternyata begitu sulitnya menemukan orang yang dengan rela dan bersedia menjadi pendengar yang budiman bagi seorang pembicara. Padahal Allah SWT menciptakan satu mulut dan dua telinga bagi manusia untuk berbicara dan mendengar. Filosofi dari penciptaan itu adalah bahwa manusia dituntut lebih banyak mendengar daripada berbicara. 
Selain itu kenyataan dalam praktek pembelajaran di kelas. Bila tidak diiringi dengan praktek menyimak (mendengarkan) maka kelas yang terdiri dari 40 orang siswa itu akan asik dengan dirinya sendiri atau kelompoknya saja. Akhirnya terjadilah suasana bak kata pepatah "biarlah anjing tetap menggonggong kapilah tetap berlalu." Tidak ada sinergi antara siswa yang bepidato dengan menggunakan bahasa Inggris dengan siswa yang menjadi pendengar. Hal itu terjadi disebabkan beberapa hal antara lain : Siswa sibuk mempersiapkan diri bila tiba gilirannya nanti, Topic atau tema pidato tidak menarik bagi siswa, Gaya berpidato yang tidak meyakinkan (biasa-biasa aja), dan lain - lain.

Berpidato dan mendengar (menyimak) merupakan dua komponen bahasa yang harus berjalan beriringan. Artinya asfek berbicara (berpidato) sama pentingnya dengan asfek mendengar (menyimak). Siswa dituntut untuk terampil berbicara dan terampil juga menyimak pembicaraan orang lain. Tetapi tuntutan terhadap asfek mendengarkan tidak ditujukan pada asfek berpidato. Sehingga timbul persepsi siswa bahasa dalam pembelajaran berpidato ini adalah berpidato saja. Mendengarkan tidak penting. Sehingga tidak jarang kelas jadi riuh tanpa alasan atau sebaliknya malah menjadi apatis. Dalam situasi seperti ini kepiawaian guru untuk mengelola kelas sangat dibutuhkan.

Adapun tujuan dari penelitian tindakan kelas (PTK) ini adalah :
- Untuk mengetahui model pembelajaran DAS (Dengar, Amati, Sampaikan) pada materi Berpidato dengan menggunakan bahasa Inggris dapat meningkatkan hasil belajar bahasa Inggris siswa di kelas IX MTsN Binjai semester ganjil tahun pelajaran 2019/2020.

- Untuk model pembelajaran DAS (Dengar, Amati, Sampaikan) pada materi Berpidato dengan menggunakan bahasa Inggris dapat meningkatkan aktivitas siswa di kelas IX MTsN Binjai semester ganjil tahun pelajaran 2019/2020.

\section{METODE PENELITIAN}

Penelitian ini dilaksanakan di kelas IX MTsN Binjai yang beralamat di jalan Pekan Baru Nomor 2A Kelurahan Rambung Barat Binjai. Jumlah siswa kelas IX MTsN Binjai Semester Ganjil Tahun Pelajaran 2019/2020 adalah 34 siswa, jumlah siswa laki-laki 22 orang dan siswa perempuan 12 orang yang diambil secara acak ditiap-tiap kelas IX. Pelaksanaan penelitian ini dilaksanakan selama tiga bulan yaitu bulan September, Oktober dan November tahun 2019, dan terdiri dari dua siklus. Pelaksanaan penelitian siklus pertama dimulai bulan September tahun 2019, dilakukan beberapa rincian sebagai berikut:

Perencanaan pertama, guru mempersiap kan RPP dan bahan ajar yang berkaitan dengan materi tentang informasi singkat, peringatan, dan 
peringatan sederhana yang akan ditampilkan saat pelaksanaan pidato, dan mengarahkan siswa untuk masuk ke kelas belajar seperti bisanya. Satu persatu siswa diabsensi, selanjutnya mempersilahkan siswa maju ke depan kelas bagi siswa yang sudah memperisapkan tugas yang telah diberikan sebelumnya, dan setelah beberapa orang siswa maju di depan kelas untuk membacakan hasil contoh materi yang akan ditampilkan saat pelaksanaan pidato tersebut tanpa penggunaan model pembelajaran DAS (Dengar, Amati, Sampaikan), maka diberikan apersepsi, dan pembelajaran berpidato dengan cara biasa (pre test), dilanjutkan dengan pembagian kelompok sekaligus pembagian tugas.

Tindakan pertama, untuk memudahkan guru mempersiapkan kelompok diskusi sebanyak jumlah siswa, masing-masing siswa mendapat satu tugas yang bertuliskan penanya, penjawab, pengkritik, dan tanggapan terhadap kritik. Setiap satu siswa bertugas sesuai tugas yang diberikan oleh guru. Dengan demikian pembelajaran tidak berpusat kepada guru semata, tapi seluruh siswa aktif mendengarkan materi yang akan ditampilkan saat pelaksanaan pidato dengan menggunakan bahasa Inggris teman nya dan kreatif dalam memberikan pertanyaan, jawaban, kritik, dan tanggapan terhadap proses pembelajaran secara keseluruhan. Proses pembelajaran tetap diprioritaskan kepada kemampuan mendengarkan dan menyimak pidato dengan menggunakan bahasa Inggris dari siswa yang sedang tampil di depan kelas. Selanjutnya proses penilaian diberikan kepada seluruh siswa. Untuk penilaian materi pidato didasarkan pada kemampuan siswa dalam menemukan beberapa contoh isi pidato dengan menggunakan bahasa Inggris yang diberikan oleh guru, sedangkaan bagi siswa lainnya diberikan penilaian sesuai dengan ketepatan pertanyaan, jawaban, kritik atau tanggapan yang disampaikan. Dalam perencanaan seluruh aspek penilaian terhadap materi pidato tanpa menggunakan model pembelajaran DAS (Dengar, Amati, Sampaikan).

(Observation)

pertama,

Observasi dilakukan oleh observer (pengamat) yaitu peneliti dan teman sejawat untuk melihat dan menilai aktivitas siswa selama pembelajaran. Bagaimana aktivitas siswa selama siswa berpidato dengan menggunakan bahasa Inggris di depan kelas dengan materi yang sudah dipersiapkan, sementara siswa yang lain mendengarkan, mengamati dan menyimak. Kesulitan - kesulitan yang diperoleh siswa yang lain pada saat berpidato tersebut dicatat, yang tujuannya agar dapat diperbaiki pada saat pelaksanaan tindakan berikutnya.

\section{Refleksi}

(Reflection)

pertama, Pada tahap refleksi ini dilakukan analisis hasil belajar (pre test 1), analisis hasil observasi aktivitas siswa dalam pembelajaran, dan mengkaji materi dalam berpidato dengan menggunakan bahasa Inggris yang belum berhasil dituntaskan oleh siswa, dan hasilnya ditulis dibuku 
catatan singkat, yang akan digunakan sebagai gambaran kekurangan yang belum tuntas yang akan diperbaiki pada tindakan lanjutan berikutnya. Jika belum tuntas maka akan dilanjutkan pada siklus kedua atau siklus berikutnya.Penelitian berikut siklus kedua dimulai pada bulan Oktober dan November 2019, dan dilakukan beberapa rincian sebagai berikut:

Perencanaan kedua, pada pertemuan berikutnya guru bersikap memberikan motivasi dan menjelaskan cara penggunaan model pembelajaran DAS (Dengar, Amati, Sampaikan), dan bersikap positif terhadap apa yang diketahui siswa. Tampilan siswa pada pertemuan sebelumnya menjadi gambara apa yang telah diketahui siswa saat itu dan sebagai batu loncatan dalam usaha menolong mengembangkan konsep-konsep yang diperlukan pada saat berpidato dengan menggunakan bahasa Inggris. Guru juga menjelaskan bagaimana cara mendengarkan,mengamati/menyimak, dan menyampaikan suatu materi tentang notice/ informasi singkat, warning/peringatan, dan caution/peringatan sederhana, dengan berpidato dengan menggunakan bahasa Inggris yang baik dan benar. Guru dan siswa berdiskusi tentang materi tentang notice/ informasi singkat, warning/ peringatan, dan caution/peringatan sederhana yang akan diberikan, dan mudah disampaikan siswa saat berpidato dengan menggunakan bahasa Inggris.
Tindakan kedua Di dalam dan di luar kelas, guru mendorong siswa untuk menggunakan bahasa Inggris setiap kali ada kesempatan untuk menyampaikan simpati, serta reaksi mereka, menggunakan aspek kebahasaan yang dapat memelihara ikatan interpersonal. Upayakan untuk berkomunikasi bahasa Inggris dengan lancar baik lisan maupun tulisan, dengan tekanan kata, intonasi, dan ejaan dan tanda baca yang tepat, serta tulisan yang jelas dan bersih. Diskusikan kesulitan yang mereka alami dalam mengungkapkan simpati dalam bahasa Inggris, serta tanggapan mereka, dan tuliskan dalam bentuk jurnal pembelajaran sederhana dalam bahasa Inggris, dengan terjemahan bahasa Indonesia jika memungkinkan.

(Observation) kedua, untuk mengetahui sejauhmana siswa dapat mendengarkan, mengamati/ menyimak, dan menyampaikan suatu materi tentang notice/ informasi singkat, warning/peringatan, dan caution/peringatan sederhana dengan berpidato dengan mengguna kan bahasa Inggris yang baik dan benar. Seorang siswa diberi tugas untuk menyampaikan pidato dengan mengguna kan bahasa Inggris yang telah disiapkan. Sedangkan siswa lainnya diberi tugas mendengarkan pidato yang dibawakan temannya. Sebelum kegiatan berlangsung terlebih guru menyampaikan asfek asfek apa saja yang akan dinilai dari kegiatan berpidato dengan menggunakan bahasa Inggris itu. Saat 
Sri Rahayu Kesumawati : Model Pembelajaran DAS ...

seorang siswa menyampai kan pidatonya dengan menggunakan bahasa Inggris secara lancar, siswa yang lainnya diberi tugas mengamati segala sesuatu yang berkaitan dengan asfek - asfek penilaian seperti yang telah disampaikan guru diawal pembelajaran. Setelah seorang siswa menyampaikan pidatonya dengan menggunakan bahasa Inggris secara lancar, maka siswa lainnya diberi kesempatan mengungkapkan /menyampaikan hasil pengamatannya terhadap pidato yang dibawakan teman. Penyampaian hasil pengamatan tersebut dapat berupa pernyataan, kritik, pendapat atau tanggapan.

Refleksi (Reflection) kedua, hasil obserrvasi yang telah dilakukan oleh guru bersama-sama siswa mencoba untuk memperbaiki kekurangan-kekurangan yang terdapat dalam pidato yang disampaikan siswa dengan menggunakan bahasa Inggris secara lancar baik dan benar. Jika pada siklus kedua ini sudah banyak perbaikan yang dilakukan, dan sudah mengalami peningkatan hasil pembelajaran dengan menggunakan model pembelajaran DAS (Dengar, Amati, Sampaikan), baik peningkatan hasil belajar siswa, maupun aktivitas siswa, maka penelitian tindakan kelas ini dihentikan.

\section{HASIL PENELITIAN DAN PEMBAHASAN}

Pada semester ganjil tahun pelajaran 2019/2020, penelitian tindakan kelas (PTK) ini dilakukan di kelas IX Madrasah Tsanawiyah Negeri Binjai. dengan jumlah 34 siswa, yang terdiri dari laki-laki 22 orang dan perempuan 12 orang. Penelitian ini berlangsung selama kurang lebih tiga bulan yang dilaksanakan dari bulan September sampai dengan bulan November semester ganjil tahun pelajaran 2019/2020, yang terletak di jalan Pakan Baru no.2A Rambung Barat Binjai. Hasil rata-rata siklus pertama ujian blok pertama sebesar 87,62, dan ujian blok kedua sebesar 88,65, dengan siswa yang nilainya masih dibawah KKM sebanyak 2 orang $(5,88 \%)$, sementara pada siklus kedua ujian blok ketiga sebesar 90,56 dan ujian blok keempat sebesar 91,53. Semua siswa nilainy sudah di atas nilai KKM, dengan nilai kriteria ketuntasan minimal (KKM sebesar 85). Dimana pada siklus pertama nilai korelasi antara ujian blok pertama terhadap ujian blok kedua sebesar 0,846 dengan nilai uji t sebesar 8,983. Dan pada siklus kedua nilai korelasi antara ujian blok ketiga terhadap ujian blok keempat sebesar 0,846 dengan nilai uji $\mathrm{t}$ sebesar 8,983. Hasil ini dapat dilihat pada tabel berikut ini: 
Tabel 1. Hasil Penelitian Tindakan Kelas Dengan Model Pembelajaran DAS (Dengar, Amati, Sampaikan) pada Materi Berpidato dengan menggunakan bahasa Inggris Siswa di Kelas IX Madrasah Tsanawiyah Negeri Binjai

\begin{tabular}{|c|c|c|c|c|c|c|c|c|c|c|}
\hline No & $\mathrm{X} 1$ & $\mathrm{X} 1 . \mathrm{X} 1$ & Y1 & Y1.Y1 & $\mathrm{X} 1 . \mathrm{Y} 1$ & $\mathrm{X} 2$ & $\mathrm{X} 2 . \mathrm{X} 2$ & $\mathrm{Y} 2$ & Y2.Y2 & $\mathrm{X} 2 . \mathrm{Y} 2$ \\
\hline 1 & 88 & 7744 & 89 & 7921 & 7832 & 91 & 8281 & 92 & 8464 & 8372 \\
\hline 2 & 86 & 7396 & 87 & 7569 & 7482 & 89 & 7921 & 90 & 8100 & 8010 \\
\hline 3 & 92 & 8464 & 93 & 8649 & 8556 & 94 & 8836 & 95 & 9025 & 8930 \\
\hline 4 & 87 & 7569 & 88 & 7744 & 7656 & 90 & 8100 & 91 & 8281 & 8190 \\
\hline 5 & 87 & 7569 & 88 & 7744 & 7656 & 90 & 8100 & 91 & 8281 & 8190 \\
\hline 6 & 88 & 7744 & 89 & 7921 & 7832 & 91 & 8281 & 92 & 8464 & 8372 \\
\hline 7 & 87 & 7569 & 88 & 7744 & 7656 & 90 & 8100 & 91 & 8281 & 8190 \\
\hline 8 & 87 & 7569 & 88 & 7744 & 7656 & 90 & 8100 & 91 & 8281 & 8190 \\
\hline 9 & 84 & 7056 & 85 & 7225 & 7140 & 87 & 7569 & 88 & 7744 & 7656 \\
\hline 10 & 87 & 7569 & 88 & 7744 & 7656 & 90 & 8100 & 91 & 8281 & 8190 \\
\hline 11 & 87 & 7569 & 88 & 7744 & 7656 & 90 & 8100 & 91 & 8281 & 8190 \\
\hline 12 & 88 & 7744 & 89 & 7921 & 7832 & 91 & 8281 & 92 & 8464 & 8372 \\
\hline 13 & 87 & 7569 & 88 & 7744 & 7656 & 90 & 8100 & 91 & 8281 & 8190 \\
\hline 14 & 89 & 7921 & 90 & 8100 & 8010 & 92 & 8464 & 93 & 8649 & 8556 \\
\hline 15 & 86 & 7396 & 87 & 7569 & 7482 & 89 & 7921 & 90 & 8100 & 8010 \\
\hline 16 & 86 & 7396 & 87 & 7569 & 7482 & 89 & 7921 & 90 & 8100 & 8010 \\
\hline 17 & 86 & 7396 & 87 & 7569 & 7482 & 89 & 7921 & 90 & 8100 & 8010 \\
\hline 18 & 86 & 7396 & 87 & 7569 & 7482 & 89 & 7921 & 90 & 8100 & 8010 \\
\hline 19 & 89 & 7921 & 91 & 8281 & 8099 & 93 & 8649 & 94 & 8836 & 8742 \\
\hline 20 & 86 & 7396 & 87 & 7569 & 7482 & 89 & 7921 & 90 & 8100 & 8010 \\
\hline 21 & 90 & 8100 & 91 & 8281 & 8190 & 93 & 8649 & 93 & 8649 & 8649 \\
\hline 22 & 87 & 7569 & 88 & 7744 & 7656 & 90 & 8100 & 91 & 8281 & 8190 \\
\hline 23 & 89 & 7921 & 90 & 8100 & 8010 & 92 & 8464 & 93 & 8649 & 8556 \\
\hline 24 & 88 & 7744 & 89 & 7921 & 7832 & 92 & 8464 & 93 & 8649 & 8556 \\
\hline 25 & 88 & 7744 & 89 & 7921 & 7832 & 91 & 8281 & 92 & 8464 & 8372 \\
\hline 26 & 89 & 7921 & 90 & 8100 & 8010 & 92 & 8464 & 93 & 8649 & 8556 \\
\hline 27 & 91 & 8281 & 92 & 8464 & 8372 & 93 & 8649 & 94 & 8836 & 8742 \\
\hline 28 & 88 & 7744 & 89 & 7921 & 7832 & 91 & 8281 & 92 & 8464 & 8372 \\
\hline 29 & 88 & 7744 & 89 & 7921 & 7832 & 91 & 8281 & 92 & 8464 & 8372 \\
\hline 30 & 84 & 7056 & 85 & 7225 & 7140 & 87 & 7569 & 88 & 7744 & 7656 \\
\hline 31 & 87 & 7569 & 88 & 7744 & 7656 & 90 & 8100 & 91 & 8281 & 8190 \\
\hline 32 & 92 & 8464 & 93 & 8649 & 8556 & 94 & 8836 & 95 & 9025 & 8930 \\
\hline 33 & 90 & 8100 & 91 & 8281 & 8190 & 92 & 8464 & 93 & 8649 & 8556 \\
\hline 34 & 85 & 7225 & 86 & 7396 & 7310 & 88 & 7744 & 89 & 7921 & 7832 \\
\hline & 2979 & $\begin{array}{c}26113 \\
5\end{array}$ & 3014 & $\begin{array}{c}26730 \\
8\end{array}$ & $\begin{array}{c}26420 \\
3\end{array}$ & 3079 & $\begin{array}{c}27893 \\
3\end{array}$ & 3112 & $\begin{array}{c}28493 \\
8\end{array}$ & $\begin{array}{c}28191 \\
9\end{array}$ \\
\hline & 87,62 & & 88,65 & \multicolumn{2}{|c|}{$r=0,846$} & 90,56 & & 91,53 & \multicolumn{2}{|c|}{$r=0,925$} \\
\hline & 87,61 & & 88,64 & \multirow{2}{*}{\multicolumn{2}{|c|}{$t=8,983$}} & 90,55 & & 91,52 & \multirow{2}{*}{\multicolumn{2}{|c|}{$t=13,808$}} \\
\hline & 8 & & 7 & & & 9 & & 9 & & \\
\hline
\end{tabular}

\section{Pembahasan}

Penggunaan

model

pembelajaran DAS (Dengar, Amati, Sampaikan) materi tentang notice/ informasi singkat, warning/ peringatan, dan caution/peringatan sederhana dalam pidato yang disampaikan siswa dengan menggunakan bahasa Inggris secara lancar baik dan benar pada penelitian tindakan kelas (PTK) yang dilakukan di kelas IX Madrasah Tsanawiyah Negeri Binjai semester ganjil tahun pelajaran 2019/2020, yang terletak di jalan Pakan Baru no.2A Rambung Barat Binjai, dengan jumlah sampel 
34 siswa, yang terdiri dari laki-laki 22 orang dan perempuan 12 orang, terdiri dari dua siklus yang berlangsung selama kurang lebih tiga bulan yang dilaksanakan dari bulan September sampai dengan bulan November tahun 2019.

Hasil yang diperoleh dari kegiatan belajar mengajar dengan menggunakan model pembelajaran DAS (Dengar, Amati, Sampaikan) pada pelajaran Bahasa Inggris ternyata dapat meningkatkan hasil belajar siswa, yang dapat dilihat dari nilai rata-rata ujian blok yang diberikan siswa. Ini dapat dilihat pada diagram batang berikut:

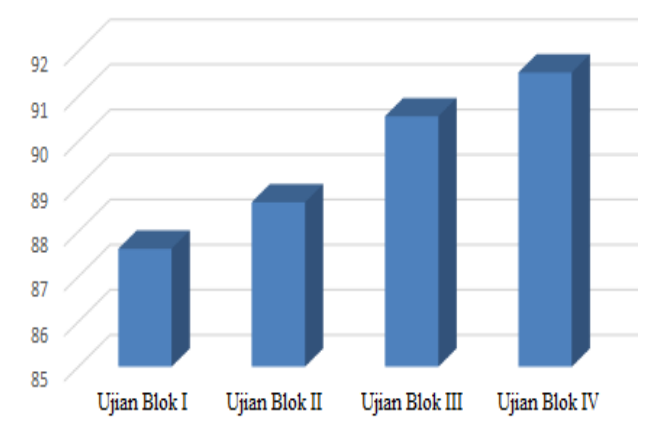

Diagram 1. Nilai Rata-rata Hasil Belajar Bahasa Inggris Siswa

Berdasarkan diagram batang di atas menunjukkan peningkatan yaitu: rata-rata siklus pertama ujian blok pertama sebesar 87,62 , dan ujian blok kedua sebesar 88,65 , dan pada siklus kedua ujian blok ketiga sebesar 90,56 dan ujian blok keempat sebesar 91,53. Sementara nilai kriteria ketuntasan minimal (KKM sebesar 85). Berikutnya, aktivitas siswa juga meningkat, hal ini dapat dilihat dari kehadiran siswa selama mengikuti kegiatan penelitian selama tiga bulan, yang tertera pada diagram batang berikut:

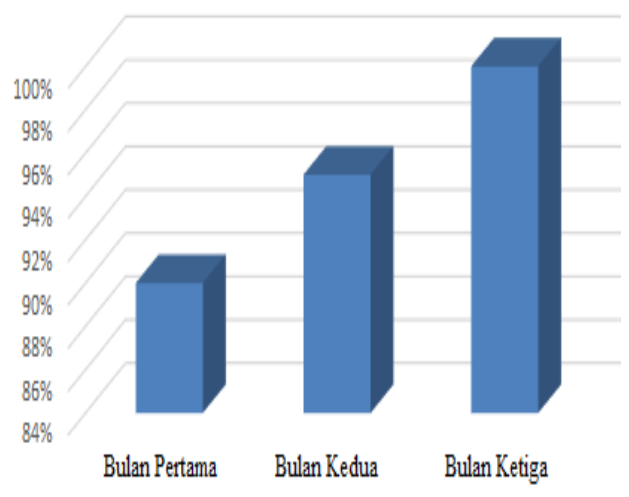

\section{Diagram 2. Hasil Kehadiran Belajar Bahasa Inggris Selama PTK}

Berdasarkan diagram batang di atas terdapat peningkatan absensi kehadiran siswa pada siklus pertama kehadiran sekitar 90\%, dan pada siklus kedua kehadiran sekitar 95\%, dan meningkat menjadi $100 \%$. Demikian pula korelasi antara uji blok I dan II sebesar 0,846 dengan nilai uji-t sebesar 8,983, dan korelasi antara uji blok III dan IV pada siklus II sebesar 0,925 dengan nilai uji-t sebesar 13.808. Ini artinya menunjukkan korelasi yang sangat signifikansi.

Berdasarkan penjelasan di atas bahwa Model Pembelajaran DAS (Dengar, Amati, Sampaikan) pada siswa kelas IX Madrasah Tsanawiyah Negeri Binjai Semester Ganjil Tahun Pelajaran 2019/2020 pada materi pidato menggunakan bahasa Inggris dapat meningkatkan hasil belajar dan aktivitas siswa.

\section{SIMPULAN}

Simpulan yang dapat diambil dari penjelasan di atas adalah: 
- Model pembelajaran DAS (Dengar, Amati, Sampaikan) pada Materi Berpidato dengan menggunakan bahasa Inggris dapat meningkatkan hasil belajar bahasa Inggris siswa di kelas IX MTsN Binjai semester ganjil tahun pelajaran 2019/2020, hal ini terlihat pada hasil perhitungan korelasi antara uji blok I dan uji blok II sebesar 0,846 dengan nilai t-test sebesar 8,983 pada siklus I, dan nilai korelasi sebesar 0,846 dengan nilai t-test sebesar 8,983 pada siklus kedua, antara ujian blok ketiga terhadap ujian blok keempat sebesar 0,846 dengan nilai uji t sebesar 8,983

- Model pembelajaran DAS (Dengar, Amati, Sampaikan) pada Materi Berpidato dengan menggunakan bahasa Inggris dapat meningkatkan aktivitas siswa di kelas IX MTsN Binjai semester ganjil tahun pelajaran 2019/2020, hal ini dapat dilihat dari peningkatan absensi kehadiran siswa pada siklus pertama kehadiran sekitar 90\%, dan pada siklus kedua kehadiran sekitar 95\%, dan meningkat menjadi $100 \%$

\section{DAFTAR RUJUKAN}

Arikunto, Suharsimi. 2018. Penelitian

Tindakan Kelas. Medan: Dalam Seminar Pendidikan di Medan.
Depdiknas. 2001. Kamus Besar Indonesia, Jakarta : Balai Pustaka

Depdiknas. 2003. Kurikulum Berbasis Kompetensi. Jakarta: Depdiknas

Depdiknas. 2003. Undang-Undang Republik Indonesia Nomor 20 Tahun 2003 Tentang system Pendidikan Nasional. Jakarta: Depdiknas

Djati Sidi, Indra. 2001. Мепији Masyarakat Belajar. Jakarta: Paramadina Iryanto, Siregar dkk. 2008. ModelModel Pembelajaran Yang Efektif. Medan: dalam Seminar Nasional Pendidikan.

Sugiyono. 2006. Metode Penelitian Pendidikan Pendekatan Kuantitatif, kualitatif dan $R \&$ $D$. Bandung: Alfabeta.

Suharsimi Arikonto. 2009. Manajemen Penelitian, Jakarta: Rineka Cipta.

Sujdana. 1982. Metodologi Statistika, Bandung: Tarsito.

Sumardi Surybrata. 2006. Psikologi Pendidikan, Jakarta: Rajawali.

Saifuddin Azwar. 2000. Realibilitas dan Validitas, Yogjakarta: Pustaka Pelajar.

Tim Redaksi. 2005. Kamus Besar Bahasa Indonesia. Jakarta: Balai Pustaka. 